\title{
USAGE OF ZINC-SILICATE COATINGS IN FRICTION CONNECTIONS
}

\author{
Nenad Fric* \\ University of Belgrade, Faculty of Civil Engineering, Belgrade, Serbia \\ Dragan Buđevac \\ University of Belgrade, Faculty of Civil Engineering, Belgrade, Serbia \\ Zoran Mišković \\ University of Belgrade, Faculty of Civil Engineering, Belgrade, Serbia \\ Zlatko Marković \\ University of Belgrade, Faculty of Civil Engineering, Belgrade, Serbia \\ Jelena Dobrić \\ University of Belgrade, Faculty of Civil Engineering, Belgrade, Serbia
}

Usage of zinc-silicate coatings as anti-corrosive protection of friction connections results in reduction of construction time and provides protection from corrosion. Such protection system has a number of advantages in respect to the widely implemented metallization procedure, prevalently in terms of speed of implementation, required training of the workforce and cost. In this paper were presented friction coefficients for different systems of anti-corrosive protection of friction connections, with emphasis on the zinc-silicate coatings and their technical characteristics and implementation methods.

Key words : Zinc-silicate coating, Friction coefficient, Friction joint connections, SRPS, Eurocode

\section{INTRODUCTION}

In the procedure of selection of anti-corrosive protection of friction surfaces, apart from the required corrosion resistance, another very important factor, and often a conclusive one, is the required friction coefficient between the elements (steel plates) connected with pre-stressed bolts. The slipping force does not prevalently depend on the friction between the surfaces in contact, but on the shearing of bulges on those surfaces [1]. From this point of view, it would be the best to leave the structure without anti-corrosive protection, that is, to connect the structural elements immediately after sandblasting. It is generally known that high friction coefficients are attained in cases of steel surfaces treated by sandblasting. However, in most of the cases this is not feasible, either because of the time required for fitting of the steel structure (long enough for the corrosion process to start developing on the sandblasted elements) or because of inability to seal the constructed friction joint connection in such a way to prevent exposure to oxygen and thus prevent corrosion development.
For these reasons, the friction surfaces must be protected from the corrosive actions, and consequently, the fiction coefficient created in them by the implemented protection system must be determined. This procedure is standardized, considering the fact that it is often conducted. In the Republic of Serbia, the friction coefficient of the friction surfaces is determined using SRPS U.E7.140:1985 standard [02]. Since 2012, the standard SRPS EN 1090-2:2012 [03] is simultaneously valid, so this procedure, with slight modifications, is harmonized with the procedure implemented in the European Union. By implementing these standards, a large number of experiments was conducted which accomplished categorization of the anti-corrosive protection systems according to the attained friction coefficients.

Usage of zinc-silicate coatings as anti-corrosive protection of friction surfaces results in reduction of construction time and provides adequate protection from corrosion. Such protection system has a number of advantages in respect to the widely implemented metallization procedure, prevalently in terms of speed of implementation, 
required training of the workforce and cost. Even though implementation of protection systems of friction surfaces based on coatings has a very long tradition in the world, it was practically implemented in Serbia for the first time in 2011, during reconstruction of the "Gazela" bridge in Belgrade. The reason for this are difficulties in procurement of the adequate coating and traditional recommendations for implementation of metallization procedure on the friction surfaces. This procedure comprises application of a certain alloy on the friction surface. The most frequently used alloy is one of aluminum and magnesium $\mathrm{AlMg}_{5}$. Metallization certainly results in high friction coefficients, but on the other hand requires adequate equipment (metallizing gun), consumption of gas and metal wire, skilled workforce, adequate protective equipment and sealing of the joints after fitting of bolts (most often by using putty) for preventing exposure to oxygen. The emergence of coatings, which simultaneously provide a satisfactory friction coefficient, caused the decrease in use of metallization process. By standardization of testing, the determination of friction in friction joints is facilitated and standardized. Regarding the continuous development of the anti-corrosion systems industry, which places a large number of coatings on the market, the determination of their characteristics for use in friction joints is considerably simplified. The values of friction coefficient were defined by SRPS standard [02] (Table 1) for various levels of treatment and systems for protection of friction joints from corrosion. In case of EN standards [3] the classes of friction surfaces are defined, and the friction coefficients which must be attained for each of them. (Table 2).

Table 1. Friction coefficients for various methods of treatment of friction joints surfaces, according to SRPS standard [02]

\begin{tabular}{|l|l|c|c|}
\hline The method of treatment of contact (friction) surfaces & \multicolumn{2}{|c|}{$\mu$} \\
\hline \multirow{4}{*}{ Unprotected } & Without a special treatment & $\mathrm{S} 235$ & $\mathrm{~S} 355$ \\
\cline { 2 - 4 } & Cleansing by fire & 0,30 & 0,30 \\
\cline { 2 - 4 } & Sandblasted & 0,40 & 0,40 \\
\cline { 2 - 4 } & Sandblasted surfaces subsequently protected by & 0,50 & 0,55 \\
\cline { 3 - 4 } & coating of aluminum alloy & 0,50 & 0,50 \\
\hline
\end{tabular}

Table 2: Friction coefficients for various methods of treatment of friction joints surfaces, according to EN standard [03]

\begin{tabular}{|l|c|c|}
\hline Surface treatment & Class & $\mu$ \\
\hline Surfaces blasted with shot or grit with loose rust removed, not pitted & $\mathrm{A}$ & 0,5 \\
\hline $\begin{array}{l}\text { Surfaces blasted with shot or grit: } \\
\text { 1. spray-metallized with a aluminium or zinc based product; } \\
\text { 2. with alkali-zinc silicate paint with a thickness of } 50 \mu \mathrm{m} \text { to } 80 \mu \mathrm{m}\end{array}$ & $\mathrm{B}$ & 0,4 \\
\hline Surfaces cleaned by wire-brushing or flame cleaning, rust removed & $\mathrm{C}$ & 0,3 \\
\hline Surfaces as rolled & $\mathrm{D}$ & 0,2 \\
\hline
\end{tabular}

From the enclosed tables, it can be clearly seen that the contemporary regulations have a more conservative approach to these issues and that they prescribe lower friction coefficients. Also, the contemporary regulations recognize zinc-silicate coatings as a form of anti-corrosive protection of friction surfaces as opposed to the national regulations adopted thirty years ago (1985) which were, until recently, the only binding regulations in the Republic of Serbia.

\section{FRICTION COEFFICIENTS FOR VARIOUS SYSTEMS OF PROTECTION OF FRICTION JOINTS FROM CORROSION}

The friction coefficients for unprotected friction surfaces, friction surfaces protected by classic anti-corrosive protection, and the surfaces protected by zinc rich ethyl-silicate coating will be presented through two referential researches. These values are significant for analysis of adequacy of zinc-silicate coatings implementation. 
In his doctoral dissertation, Vlajić [01] experimentally, using standardized procedures, determined friction coefficients on the friction surfaces protected by:

- metallization using aluminum and magnesium alloy AIMg5,

- metallization using pure aluminum,

- classic anti-corrosion protection (chlorine primer manufactured by "Zorka“ Šabac),

- chlorine primer coating with addition of silicon carbide (or carborundum) SiC.

In addition, for the purpose of comparison, in the same research was determined friction coefficient on the surfaces without anti-corrosive protection, for two different levels of treatment: by sandblasting and by polishing.

The initial idea was to improve the characteristics of classic anti-corrosive protection and increase the friction coefficient by adding silicon carbide, which would make it applicable in friction joints. Silicon carbide belongs to inorganic compounds with extremely high toughness and relatively low production cost. For this reason, it became widely used in industry, especially for production of sandpapers, abrasive materials and similar.

The author conducted an extensive experimental research (a total of 260 specimens) and determined friction coefficients (table 3 ) with small standard deviations, which confirms quality and reliability of this experimental research.

The obtained values for the surfaces treated by sandblasting and metallization are considerably higher than those defined by Eurocode which makes experimental determination of friction coefficients for the purposes of construction of structures increasingly important. By adding carborundum to the classical coatings, friction coefficient was increased for more than $30 \%$, which justified this procedure. It was concluded that better results could be achieved by applying carborundum on only one friction surface. In this way, crushing of the grains in mutual contact at the moment when the bolts are being tightened would be prevented.

Table 3: Friction coefficients for various methods of treatment of friction areas - Vlajić [01]

\begin{tabular}{|c|l|c|c|c|}
\hline \multirow{2}{*}{ Steel grade } & Surface treatment & Friction coeff. $\mu$ & $\begin{array}{c}\text { Standard } \\
\text { deviation [\%] }\end{array}$ & $\begin{array}{c}\text { Number of } \\
\text { samples }\end{array}$ \\
\hline \hline \multirow{4}{*}{ S235 } & sandblasting & 0,616 & 4,30 & 24 \\
\cline { 2 - 5 } & sandblasting + metallization (AIMg5) & 0,548 & 5,20 & 188 \\
\cline { 2 - 5 } & sandblasting + metallization (AI) & 0,363 & 7,80 & 24 \\
\cline { 2 - 5 } & sandblasting + „hlorvenmijum“+ SiC & 0,308 & 2,44 & 24 \\
\cline { 2 - 5 } & sandblasting + „hlorvenmijum“ & 0,235 & 8,82 & 24 \\
\cline { 2 - 5 } & polishing & 0,156 & 6,80 & 12 \\
\hline
\end{tabular}

Wylliam Husson in the research which is the integral part of his thesis [4], among other things, determined friction coefficients on the surfaces treated in two ways:

- steel plates of S355 class, sand blasted to Sa2,5 level, in all according to the standard ISO-8501-1 [5], subsequently coated with two-component zinc rich ethyl - silicate coating „TEMASIL 90“, manufactured by „Tikkurila Coatings",

- weathering steel plates with commercial name "COR-TEN B“ [6] manufactured by "Ruukki“, in the first batch sand blasted and immediately tightened with bolts, and in the second batch sandblasted and exposed to weather effects prior to tightening.
The coating, used during research, has already been widely used in construction of wind turbines and it can be used as a single coating, or as a primer in a complex system of anti-corrosion protection. In both cases it is applied in a layer of $50 \mu \mathrm{m}$ to $80 \mu \mathrm{m}$ with the zinc content ranging between 70 and $90 \%$.

Weathering steel contains elements allowing formation of patina in the event of exposure to weather effects. A number of samples was formed from the plates which did not exhibit rust, and the remaining number from the plates exposed to weather effects which were fitted among the samples after formation of patina. The product "COR-TEN B“, according to its mechanical properties corresponds to the steel of the S355J0W(P) class. 
The friction coefficients presented in Table 4 were determined for formed specimens. It is important to point out that the friction coefficients prescribed for the class $B$ of friction surfaces were not attained on the samples protected by zinc rich coating.

Table 4: Friction coeff. for various methods of treatment of friction surfaces - Husson [04]

\begin{tabular}{|l|l||c|c|}
\hline Steel grade & Surface treatment & Friction coeff. $\mu$ & Number of samples \\
\hline Cor-Ten B & sandblasting & 0,591 & 3 \\
\hline Cor-Ten B & sandblasting + atmospherics & 0,629 & 3 \\
\hline Cor-Ten B & sandblasting + atmospherics & 0,611 & 5 \\
\hline S355 & sandblasting + Temasil 90 & 0,310 & 17 \\
\hline
\end{tabular}

\section{ZINC-SILICATE COATING „RESIST 86“ MANUFACTURED BY „JOTUN"}

Zinc-silicate coating „Resist 86“ (manufactured by „Jotun“, Norway) as anti-corrosive protection of friction surfaces of the "Gazela" bridge was selected assuming that the friction coefficient higher than 0,4 can be achieved between two steel plates protected by this system. This is simultaneously the first implementation of zincsilicate coatings on the friction surfaces in the Republic of Serbia. It was the first time (2010) that the value of friction coefficients which can be used on friction surfaces with this system of anti-corrosion protection applied was determined for the bridge reconstruction purposes [07]. The procedure of determination of friction coefficient was conducted in all according to the provisions of the SRPS U.E7.140:1985 standard [02].

\section{TECHNICAL CHARACTERISTICS AND METHOD OF APPLICATION OF ZINC-SILI- CATE COATING "RESIST 86"}

This system of anti-corrosive protection was designed by the manufacturer [8] for "heavy duty" corrosion protection system, both:

- as the primer (first layer) in multi-layered systems, or

- as a single-layer coating for protection of steel surfaces in medium-to-severe corrosive environments.

It is a two component, fast curing, zinc rich ethylsilicate coating. It consists of component $A$ and powdery component $B$ (dry zinc dust) which are mixed in the ratio $A: B=8: 2,6$. Component A must be well shaken before use, since sediment is bound to settle while it is still. It is very important to pay heed to the fact that the liquid component $A$ has a limited shelf life, which is 6 months stored in dry and dark place at a temperature of $23^{\circ} \mathrm{C}$. Exposure to higher temperatures shortens the expiry time and causes conversion of liquid into a jelly. Because of these facts, implementation of zinc-silicate coating, "Resist 86", especially in summer season, calls for a careful planning both in practical application and in conducting of experimental research.

The manufacturer prescribes minimal, maximal and optimal coating thickness (Table 5). It is particularly stressed that if the film thickness exceeds $120 \mu \mathrm{m}$ there is a high probability that the film would "crack".

Table 5. Prescribed coating film thickness in wet and dry states [08]

\begin{tabular}{|c|c|c|c|}
\hline \multirow{2}{*}{$\begin{array}{c}\text { Film } \\
\text { condition }\end{array}$} & \multicolumn{3}{|c|}{ Film thickness [um] } \\
\cline { 2 - 4 } & Minimum & Maximum & Typical \\
\hline \hline Dry & 50 & 90 & 75 \\
\hline \hline Wet & 75 & 135 & 115 \\
\hline
\end{tabular}

After the completed cleaning using sandblasting, dust is removed from the cleaned surfaces using compressed air of manually using brushes, which completes the preparations for application of anti-corrosive protection.

In the course of application of zinc-silicate coating, it is necessary that the substrate temperature is no less than $5^{\circ} \mathrm{C}$, but also no less than $3{ }^{\circ} \mathrm{C}$ above the dew point. In principle, curing of the zinc-silicate coatings requires moisture. At low relative humidity of air, curing is increased by sprinkling of coating film with fresh water or by artificial increasing of the environment humidity (Figure 1a).

In order to create a desired thickness in dry state, the coating thickness in wet state (immediately after application) was measured, using wet paint comb gauge (Figure $1 \mathrm{~b}$ and $1 \mathrm{c}$ ).

Each of the coating application techniques, either using compressor or manual, requires continuous stirring in order to avoid settling of the heavy zinc particles, which is a fast developing 
process. At the moment of application of any of two layers of anti-corrosion protection, the weather conditions must be in accordance with the conditions prescribe by the manufacturers, which is measured on the site and registered in the log book.

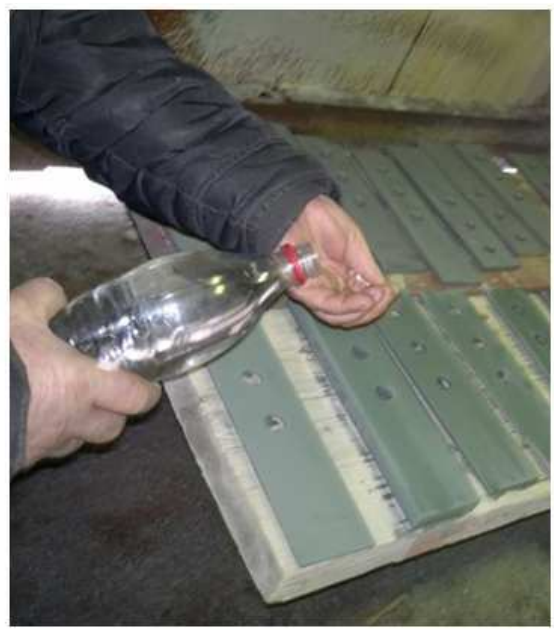

a)

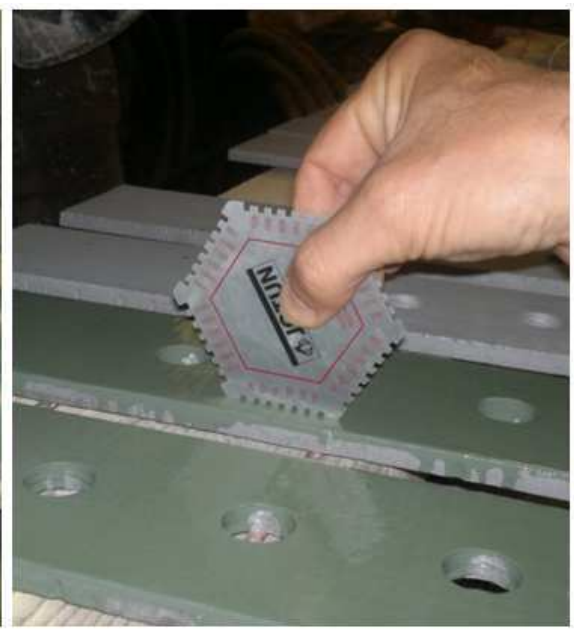

b)

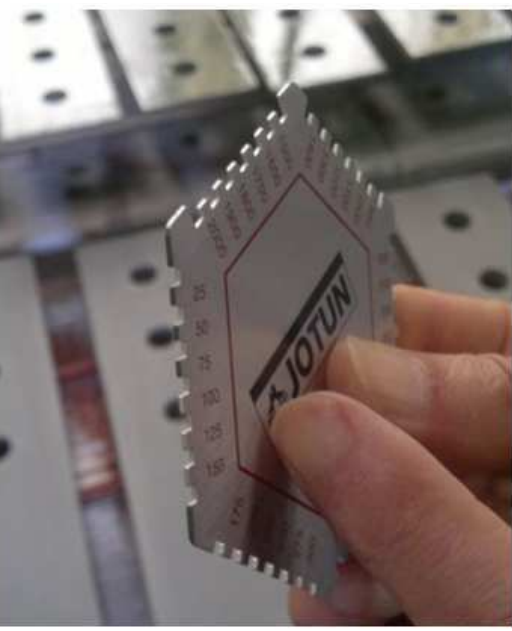

c)

Figure 1: a) Spraying of film with fresh water in low humidity conditions; b) and c) Measuring of the coating thickness in wet state [09]

\section{FRICTION COEFFICIENTS IN CASE OF IMPLEMENTATION OF ZINC-SILICATE COATING "RESIST 86"}

The fact the zinc-silicate coating „Resist 86“ never before was used for friction joints, called for an extensive experimental research aimed at determining of friction coefficient. Friction coefficient was determined by testing of a total of 48 specimens, and a particular emphasis was placed on analysis of the impact of time interval between the application of coating and tightening of the bolts, for the attained friction coefficients. The test [07] was divided in two parts. The first, where the tightening of the bolts and testing of the specimens took place at the same moment - one after another, and the second part where the samples were tested after a certain time passed since the bolts had been tightened. The initial tests demonstrated that in a short time period after application of the coating (up to 3 days) it is not possible to attain the required friction coefficient. The obtained friction coefficients of 0,29 to 0,38 , but also a prominent dissipation of results, indicated the need to perform tests after a longer time period since the moment of application of the coating. Accordingly, the tests were performed 6,8 and 10 days since the moment of application of the coating, on 4 specimens for each time period. The attained friction coefficients were between 0,46 and 0,50 but there was also a standard deviation of less than $8 \%$ which is within the permissible boundaries according to the standard.

The obtained results certainly justified implementation of "Resist 86" coating in the friction surfaces of the "Gazela" bridge, but they raised the question of technology and duration of construction regarding the anti-corrosive protection of friction surfaces. Since it was a reconstruction of the existing bridge structure, it was conducted in phases, and it was very important to provide restoration of the prefabricated elements of the bridge (plates and bolts) into the original state in as short time as possible after their dismantling. For that reason, a third part of this research was conducted, where the friction coefficients were determined 10 days after application of the coating, and tightening of the bolts to the full torque was accomplished $72 \mathrm{~h}$ after application of the coating. The obtained results allowed improvement of technology of reconstruction of the bridge construction and considerable shortening of time required for works on the anti-corrosive protection. The bolt tightening $72 \mathrm{~h}$ after application of the coating and loading of the structure 10 days after that yielded the best results, i.e. the best friction coefficients between 0,49 and 0,50.

Following the made conclusions, the contractor developed of a system of supporting the platess using a long grub screws (Figure 2). In this way, it was made possible to tighten the bolts $72 \mathrm{~h}$ after application of the coating. After tightening of all the joints, more than ten days passed until they were exposed to service loads. 

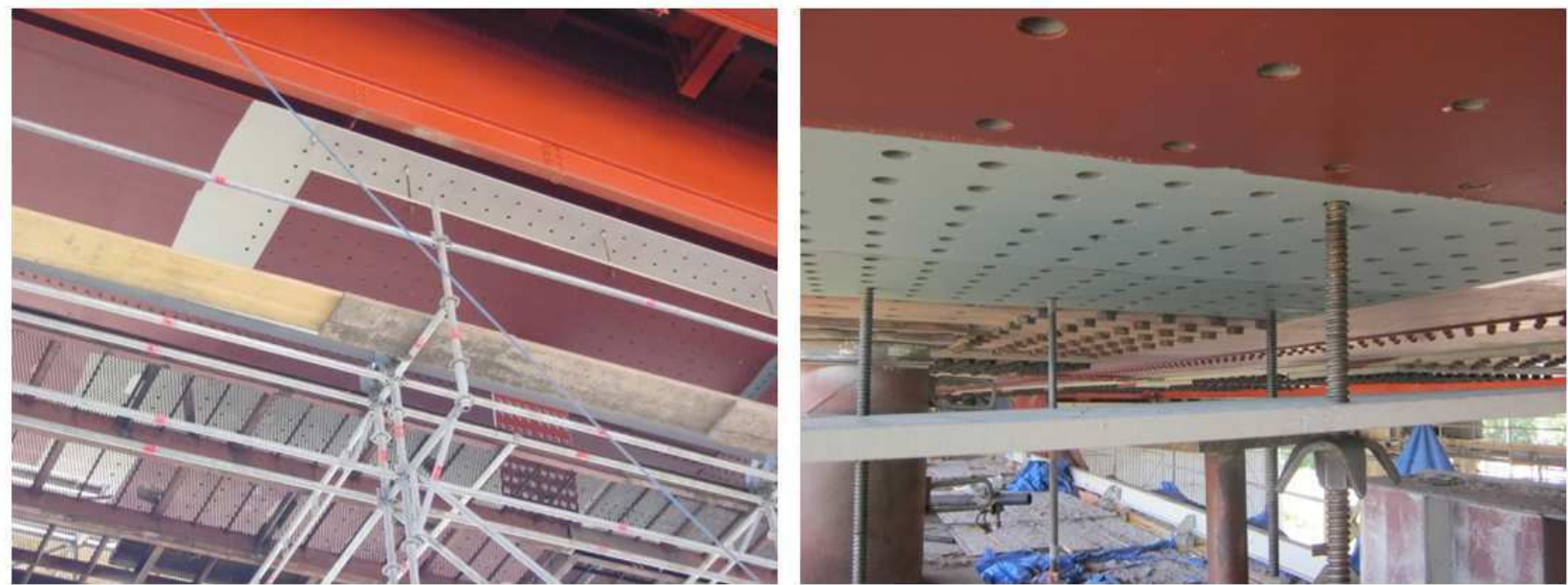

Figure 2: Reconstruction of the „Gazela“ bridge in Belgrade - implementation of zinc-silicate coating „Resist 86 " as anti-corrosive protection of friction surfaces [09]

\section{CONCLUSION}

Implementation of zinc-silicate coatings represents an efficient way of anti-corrosive protection of friction surfaces. The main precondition for them to substitute the metallization procedure is attainment of required friction coefficients in friction joints. However, the required friction coefficients for the surface treatment category $A$ and $B$, according to Eurocode, $\mu \geq 0,4$ and $\mu \geq 0,50$ respectively, cannot be attained with any zinc-silicate coating. Because of that, it is important, prior to implementation of coating in the friction joints, to determine friction coefficient which can be attained. In the case of zinc-silicate coating „Resist 86“ manufactured by „Jotun" the best results are achieved by tightening the bolts $72 \mathrm{~h}$ after applying the coating and by loading the structure 10 days after that, which was confirmed by the experimental research for the purposes of reconstruction of the "Gazela" bridge in Belgrade. Such system of protection of friction surfaces, applied in the described way, provided good results and facilitated shortening of time needed for application of anti-corrosive protection. Certainly, technology of bridge construction differs from their reconstruction, in terms of dynamics. Therefore, it will be useful to determine friction coefficients for longer period between application of the coating on the steel structure elements, bolt tightening and exposing those elements to service loads. By following the analogy of the presented results of experimental researches, it can be expected that the attained friction coefficients will be even higher, i.e. more favorable from the aspect of slipping resistance of the joints.

\section{REFERENCES}

1) Lj. Vlajić: „Ponašanje spojeva sa visokovrednim zavrtnjevima pri eksploatacionom i graničnom opterećenju“, Doktorska disertacija, Univerzitet u Nišu, 1993, 122 str.

2) SRPS U.E7.140:1985: „Spojevi sa vijcima visoke klase čvrstoće kod nosećih čeličnih konstrukcija - Tehnički uslovi”, 1985.

3) SRPS EN 1090-2:2012: "Execution of steel structures and aluminium structures - Part 2: Technical requ for the execution of steel structures", Institute for standardization of Serbia, 2012.

4) W. Husson: „Friction Connections with Slotted Holes for Wind Towers", Licentiate Theses, Luleå University of Technology, 2008, $192 p$.

5) ISO 8501-1:2007: „Preparation of steel substrates before application of paints and related products - Visual assessment of surface cleanliness - Part 1: Rust grades and preparation grades of uncoated steel substrates and of steel substrates after overall removal of previous coatings", International organization for standardization, 1998.

6) Hot-rolled weather resistant COR-TEN, http://www.ruukki.com/Steel/Steel-products/ Hot-rolled-steels/Hot-rolled-weather-resistant-COR-TEN, dostupno 30. septembra 2014., $17: 30$

7) GP „Mostogradnja“ AD, Vlajkovićeva 19a, Biro za kontrolu kvaliteta, Laboratorija za ispitivanje: „Izveštaji o ispitivanju koeficijenta trenja „ $\mu^{\prime \prime}$ tarnog spoja pritegnutog V.V. vijc- 
ima, pripremljenog po sistemu „RESIST 86“ (Jotun), april-jun 2010. Godine“, Beograd.

8) Jotun Norway: „Technical data sheet for Resist 86“, http://wwwda.jotun.com/jotun/ paints/20020020.nsf/wvwProductDatabase/ F89C5FE225EEC6CEC12568F500261088/ \$file/TDS $\% 20$ - \%20Resist $\% 2086 \% 20$ $\% 20$ English \% 20 (uk ) \% 20 - \% 20 Is sued.11.06.2012.pdf, dostupno 11. Oktobra 2013., 18:30
9) N. Fric: „Teorijsko i eksperimentalno istraživanje gubitaka sile prednaprezanja u visokovrednim zavrtnjevima“, Doktorska disertacija, Građevinski fakultet Univerziteta u Beogradu, 2015, 305 str.

Paper sent to revision: 01.02.2016.

Paper ready for publication: 07.03.2016. 
doi:10.5937/jaes14-10450

\section{PRIMENA CINK-SILIKATNIH PREMAZA U TARNIM SPOJEVIMA}

Nenad Fric, Univerzitet u Beogradu, Građevinski fakultet, Beograd Dragan Buđevac, Univerzitet u Beogradu, Građevinski fakultet, Beograd Zoran Mišković, Univerzitet u Beogradu, Građevinski fakultet, Beograd Zlatko Marković, Univerzitet u Beogradu, Građevinski fakultet, Beograd Jelena Dobrić, Univerzitet u Beogradu, Građevinski fakultet, Beograd Milan Spremić, Univerzitet u Beogradu, Građevinski fakultet, Beograd

Primenom cink-silikatnih premaza kao antikorozione zaštite tarnih površina skraćuje se vreme izgradnje konstrukcija i obezbeđuje zaštita od korozije. Ovakav sistem zaštite ima niz prednosti u odnosu na široko primenjivan postupak metalizacije, pre svega u smislu brzine sprovođenja, zahtevane kvalifikovanosti radne snage i cene. $U$ ovom radu prikazani su koeficijenti trenja za različite sisteme antikorozione zaštite tarnih spojeva, sa akcentom na cink-silikatne premaze i njihove tehničke karakteristike i način primene.

Ključne reči: Cink-silikatni premaz, Koeficijent trenja, Tarne površine, SRPS, Evrokod 